\title{
IRSL AND POST-IR IRSL RESIDUAL DOSES RECORDED IN MODERN DUST SAMPLES FROM THE CHINESE LOESS PLATEAU
}

\author{
JAN-PIETER BUYLAERT ${ }^{1,2}$, CHRISTINE THIEL $^{1,3}$, ANDREW S. MURRAY $^{1}$, \\ DIMITRI A.G. VANDENBERGHE ${ }^{4}$, SHUANGWEN YI ${ }^{5}$ and HUAYU $\mathrm{LU}^{5}$ \\ ${ }^{I}$ Nordic Laboratory for Luminescence Dating, Department of Earth Sciences, Aarhus University, \\ Risø DTU, DK-4000 Roskilde, Denmark \\ ${ }^{2}$ Radiation Research Division, Risø National Laboratory for Sustainable Energy, Technical University of Denmark, \\ DK-4000 Roskilde, Denmark \\ ${ }^{3}$ Leibniz Institute for Applied Geophysics, S3: Geochronology and Isotope Hydrology, 30655 Hannover, Germany \\ ${ }^{4}$ Laboratory of Mineralogy and Petrology, Department of Geology and Soil Science, Ghent University, B-9000 Ghent, Belgium \\ ${ }^{5}$ School of Geographical and Oceanographical Sciences, Nanjing University, Nanjing 210093, China
}

\begin{abstract}
Using a set of modern/young ( 0 to about 200 years old) dust samples collected from the Chinese Loess Plateau the bleachability of IRSL measured at $50^{\circ} \mathrm{C}\left(\mathrm{IR}_{50}\right)$ and post- $\mathrm{IR}_{50}$ elevated temperature IRSL (measured at $225^{\circ} \mathrm{C}$ and at $290^{\circ} \mathrm{C}$ ) is investigated by measuring the apparent (residual) doses recorded by these signals. Doses recorded by quartz OSL are used as a reference. Allowing for differences in dose rates it seems that both IRSL and post-IR IRSL signals yield residual doses that are significantly larger than the doses measured in quartz. These residual doses can be largely explained by thermal transfer caused by preheating. Nevertheless, we advise against the use of a low temperature preheat $\left(<200^{\circ} \mathrm{C}\right)$ with $\mathrm{IR}_{50}$ to date loess samples because, as has been reported before, the signal appears to be thermally unstable. In general, we conclude that it may not be advisable to apply post-IR IRSL dating to Chinese loess samples where residuals of up to $\sim 20$ Gy are a significant fraction of the total dose. However, these residuals quickly become unimportant when dating older samples, and this is the age range in which post-IR IRSL dating is likely to be most useful.
\end{abstract}

Keywords: modern dust, IRSL, polymineral fine-grains, post-IR IRSL, loess, China.

\section{INTRODUCTION}

Quartz is generally seen as the preferred dosimeter in luminescence dating studies (Murray and Olley, 2002), especially in the younger age range (Madsen and Murray, 2009). Many studies of Chinese loess have employed quartz optically stimulated luminescence (OSL) to establish a chronology both using coarse (e.g. Stevens et al., 2006; Buylaert et al., 2008; Lai, 2010) and fine (e.g.

Corresponding author: J. P. Buylaert e-mail: jabu@risoe.dtu.dk
Watanuki et al., 2003; Lu et al., 2007) grains. Unfortunately Chinese loess (dust) may not contain sufficient coarse quartz grains (at least in the sand fraction), and the isolation of fine-grained quartz is time-consuming (Roberts and Wintle, 2001; Roberts, 2008). In addition, the quartz OSL signal has a limited dose range; because of the high dose rate in loess, quartz cannot usually be used to date older than $\sim 50 \mathrm{ka}\left(\mathrm{D}_{\mathrm{e}}>\sim 150 \mathrm{~Gy}\right.$; Buylaert et al., 2007; 2008). Polymineral fine-grains are very easily prepared and are commonly used with infrared (IR) stimulation and a blue detection window to date loessic sedi- 
ments (e.g. Musson et al., 1994; Frechen, 1999; Tsukamoto et al., 2001). It is assumed that luminescence emissions from feldspars dominate the signal. It has also been shown that the loess infrared stimulated luminescence (IRSL) signal grows to much higher doses than does the OSL from quartz (e.g. Buylaert et al., 2007). However, the luminescence behaviour (such as bleachability, anomalous fading, and sensitivity change) of polymineral finegrains is not yet well understood, and their reliability for dating remains to be established (Roberts, 2008; Roberts and Wintle, 2003). Other work on polymineral fine-grains has focused on trying to extract a quartz dominated OSL signal from this material with a so-called double-SAR (single aliquot regenerative) dose measurement procedure (Banerjee et al., 2001) and detection in the UV spectrum (e.g. Roberts and Wintle, 2001; Zhang and Zhou, 2007; Wang et al, 2006; Zhou et al., 2010).

Buylaert et al. (2007) demonstrated that the IRSL signal measured at $50^{\circ} \mathrm{C}$ (defined here as $\mathrm{IR}_{50}$ ) from polymineral fine-grains extracted from the Luochuan type section shows anomalous fading ( $g_{2 \text { days }}$ of $\sim 3 \%$ /decade); this required corrections to the apparent age of $\sim 35 \%$ using the model proposed by Huntley and Lamothe (2001). Recently, Thomsen et al. (2008) identified the potential of stimulating sand-sized grains of feldspar with IR while the sample is held at elevated temperature. They observed a substantially lower fading rate using a post-IR IRSL measurement protocol (in which an $\mathrm{IR}_{50}$ is immediately followed by IR stimulation at some elevated temperature) compared to that from a conventional protocol using only an $\mathrm{IR}_{50}$ signal. Buylaert et al. (2009) showed that these conclusions applied to the natural signal from sand-sized K-feldspar grains, and Thiel et al. (2011a) showed that the conclusions could be extended to polymineral fine-grains extracted from European loess.

The potential of SAR based IRSL and post-IR IRSL measurements on polymineral fine-grains extracted from Chinese loess has not yet been fully explored, and there are no studies of the bleachability of the IRSL and postIR IRSL signals of polymineral fine-grains using modern dust. Feldspars bleach more slowly than quartz (GodfreySmith et al., 1988; Thomsen et al., 2008) and, although complete daylight bleaching of fine-grained dust material is usually assumed, there are suggestions that bleaching processes may be hampered by superficial coatings (as suggested in Prescott (1983) for TL signals of quartz extracted from aeolian sands in Australia). In this paper, we use polymineral fine-grains of modern dust samples collected across the Chinese Loess Plateau to investigate the completeness of bleaching of both the IRSL signal measured with the sample held at $50^{\circ} \mathrm{C}$, and the post-IR IRSL signals measured at elevated temperature $\left(225^{\circ} \mathrm{C}\right.$ and $290^{\circ} \mathrm{C}$ ). All feldspar signals are measured in the blueviolet part of the spectrum. The dose estimates are evaluated by comparison with the OSL results from quartz grains; these are known to be accurate in this age range (Madsen and Murray, 2009). Residual feldspar doses are discussed in terms of thermal transfer and incomplete bleaching. Finally, we address the question of whether a low temperature preheat can be used when dating loess using the $\mathrm{IR}_{50}$ signal.

\section{SAMPLES AND MEASUREMENT DETAILS}

Three modern/young samples collected from the top few $\mathrm{cm}$ of apparently undisturbed loess sections in the Chinese Loess Plateau were used in this study, together with three superficial dust samples (roofs of buildings in $\mathrm{Xi}$ 'an and Beijing, and a car bumper sample) (see Table 1 for details). The Beijing dust sample (TPU) was collected in April 2007 from the top of air-conditioning units on the roof of the Geography Department of Peking University, and the car bumper sample (CB) was sampled after a $\sim 7$ days field trip in the Chinese Loess Plateau in April 2005. Both samples were taken from $<<1 \mathrm{~mm}$ thick layer of dust. In this study we also make use of two old true loess samples to investigate the stability and preheat dependence of the (post-IR) IRSL signals (sections 3 and 6): sample A42 from the Luochuan section taken in loess layer L9 with an expected age of $\sim 900 \mathrm{ka}$ (Buylaert et al., 2007) and sample A7 from the Zhongjiacai section, dated with quartz OSL by Buylaert et al. (2008) to $29.0 \pm 1.4 \mathrm{ka}$.

Polymineral fine-grains $(4-11 \mu \mathrm{m})$ were extracted from all the samples in the usual manner $\left(\mathrm{HCl}\right.$ and $\mathrm{H}_{2} \mathrm{O}_{2}$ treatment and Stokes' settling) and deposited on aluminium discs (e.g. Frechen et al., 1996). About $1 \mathrm{mg}$ of sample was used per disc. Sand-sized $(63-90 \mu \mathrm{m})$ quartz grains were extracted using wet sieving, $\mathrm{HCl}$ and $\mathrm{H}_{2} \mathrm{O}_{2}$ treatment and etching for $40 \mathrm{~min}$ in concentrated $\mathrm{HF}$ to remove feldspars. For two superficial dust samples (TPU from the top of a building in Beijing and CB from the car bumper), no sand-sized quartz grains could be extracted. Instead, we extracted fine-grained $(4-11 \mu \mathrm{m})$ quartz grains using a 3 days hydrofluorosilicic acid etch (Zhang and Zhou, 2007); for sample CB a coarse-silt (36-50 $\mu \mathrm{m})$ quartz fraction was obtained by wet sieving and a $40 \mathrm{~min}$ concentrated HF digestion. After acid treatment all quartz fractions were checked for the presence of a significant IRSL signal. Some 63-90 $\mu \mathrm{m}$ fractions required another 40 min of concentrated HF to obtain clean quartz. Coarse-grained quartz was mounted on stainless steel discs using a $8 \mathrm{~mm}$ mask and silicon spray to produce large aliquots. Except for the 4-11 $\mu \mathrm{m} \mathrm{CB}$ sample, all the quartz fractions were found to be pure after acid treatment. (The CB sample was measured with a double-SAR protocol (Banerjee et al., 2001) to obtain a quartzdominated signal - see caption Table 1 for details).

All luminescence measurements were made with a Risø TL/OSL DA-15 reader equipped with IR diodes emitting at $875 \mathrm{~nm}$, blue diodes emitting at $470 \mathrm{~nm}$, and ${ }^{90} \mathrm{Sr} /{ }^{90} \mathrm{Y}$ beta sources calibrated for fine-grains on aluminium and coarse-grains on stainless steel discs using quartz (Bøtter-Jensen et al., 2003). The quartz equivalent doses 
$\left(D_{e}\right)$ were measured using a UV filter (U-340) with a SAR protocol (Murray and Wintle, 2000) appropriate for young samples (preheat $180^{\circ} \mathrm{C}$ for $10 \mathrm{~s}$; cut-heat of $160^{\circ} \mathrm{C}, 40 \mathrm{~s}$ stimulation at $280^{\circ} \mathrm{C}$ after every SAR cycle). The first $0.8 \mathrm{~s}$ of the signal less a background derived from the last $4 \mathrm{~s}$ was used for calculations. The IRSL signals from polymineral fine-grains, both at $50^{\circ} \mathrm{C}$ and elevated temperature, were detected through a blue filter combination (Schott BG39 + Corning 7-59, transmission $320-460 \mathrm{~nm})$. In the SAR protocols used for IRSL measurements the thermal treatment (preheat) of the test dose was kept the same as for the natural and regenerative doses (Blair et al., 2005). Several preheating (and storage at room temperature) regimes for low (room temperature to $\sim 60^{\circ} \mathrm{C}$ ) temperature IRSL measurements on polymineral fine-grains exist (e.g. 1 month storage at room temperature $+5 \mathrm{~min}$ at $220^{\circ} \mathrm{C}$, Lang et al., $2003 ; 160^{\circ} \mathrm{C}$ for $4 \mathrm{~h}$, Lian and Huntley, $1999 ; 16 \mathrm{~h}$ at $140^{\circ} \mathrm{C}, \mathrm{Li}$ and
Wintle, 1992; one month room temperature storage $+16 \mathrm{~h}$ at $150^{\circ} \mathrm{C}$, Frechen and Dodonov, $1999 ; 250^{\circ} \mathrm{C}$ for 60 s, Auclair et al., 2007). Because we measure the $\mathrm{IR}_{50}$ signal with a SAR protocol we have chosen practical short preheating times of $60 \mathrm{~s}$. We measured $\mathrm{IR}_{50}$ both with a stringent $250^{\circ} \mathrm{C}$ preheat (Buylaert et al., 2007) and also with a low temperature preheat of $150^{\circ} \mathrm{C}$. Further details of the thermal treatments and stimulation conditions for the individual SAR protocols are given in Table 2. The net IRSL signals were derived from the initial $0.8 \mathrm{~s}$ of the decay curve minus a background calculated using the last $9.6 \mathrm{~s}$.

\section{WHY USE POST-IR IRSL SIGNALS?}

Laboratory measurements have indicated that doses measured using post-IR IRSL are less affected by anomalous fading than those measured using IRSL at $50^{\circ} \mathrm{C}$

Table 1. Sample details and equivalent doses for the modern/young samples. (1) $D_{e}$ was measured using a double SAR procedure (Banerjee et al., 2001). The required length of IR stimulation time in the double SAR procedure was determined using a plateau test (Wang et al., 2006); an IR bleach of $100 \mathrm{~s}$ at $60^{\circ} \mathrm{C}$ was found to be sufficient. (2) The $D_{\mathrm{e}}$ values of the 4-11 $\mu \mathrm{m}$ fractions are not included in the average.

\begin{tabular}{|c|c|c|c|c|c|c|c|c|}
\hline \multirow{2}{*}{\multicolumn{2}{|c|}{ Code Location }} & \multirow[b]{2}{*}{ Sample type } & \multicolumn{2}{|c|}{ Quartz } & \multicolumn{4}{|c|}{ Polymineral fine-grains $(4-11 \mu \mathrm{m}), \mathrm{D}_{\mathrm{e}}(\mathrm{Gy})$} \\
\hline & & & $\begin{array}{l}\text { OSL, } D_{e} \\
\text { (Gy) }\end{array}$ & $\begin{array}{l}\text { grain } \\
\text { size } \\
(\mu \mathrm{m})\end{array}$ & $\begin{array}{c}\mathrm{IR}_{50} \\
\left(\mathrm{Ph}: 150^{\circ} \mathrm{C} / 60 \mathrm{~s}\right)\end{array}$ & $\begin{array}{c}\mathrm{IR}_{50} \\
\left(\mathrm{Ph}: 250^{\circ} \mathrm{C} / 60 \mathrm{~s}\right)\end{array}$ & $\begin{array}{c}\mathrm{pIRIR} 225 \\
\left(\mathrm{Ph}: 250^{\circ} \mathrm{C} / 60 \mathrm{~s}\right)\end{array}$ & $\begin{array}{c}\text { plRIR } 290 \\
\left(\mathrm{Ph}: 320^{\circ} \mathrm{C} / 60 \mathrm{~s}\right)\end{array}$ \\
\hline D6 & $\begin{array}{l}\text { Zhou he zhen bei } \\
\left(37^{\circ} 07.910^{\prime} \mathrm{N}, 108^{\circ} 40.887^{\prime} \mathrm{E}\right)\end{array}$ & $\begin{array}{l}\text { top few } \mathrm{cm} \text { of } \\
\text { loess section }\end{array}$ & $\begin{array}{c}0.65 \pm 0.10 \\
(n=9)\end{array}$ & $63-90$ & $\begin{array}{l}1.01 \pm 0.03 \\
(n=5)\end{array}$ & $\begin{array}{l}2.79 \pm 0.09 \\
(n=6)\end{array}$ & $\begin{array}{l}6.9 \pm 0.5 \\
(n=6)\end{array}$ & $\begin{array}{l}19 \pm 5 \\
(n=6)\end{array}$ \\
\hline D9 & $\begin{array}{l}\text { Shi mao } \\
\left(37^{\circ} 56.183^{\prime} \mathrm{N}, 109^{\circ} 58.930^{\prime} \mathrm{E}\right)\end{array}$ & $\begin{array}{l}\text { top few } \mathrm{cm} \text { of } \\
\text { loess section }\end{array}$ & $\begin{array}{c}0.13 \pm 0.02 \\
(n=17)\end{array}$ & $63-90$ & $\begin{array}{c}0.41 \pm 0.07 \\
(n=3)\end{array}$ & $\begin{array}{c}2.07 \pm 0.11 \\
(n=7)\end{array}$ & $\begin{array}{c}3.8 \pm 0.2 \\
(n=6)\end{array}$ & $\begin{array}{c}9.1 \pm 0.6 \\
(n=6)\end{array}$ \\
\hline D10 & $\begin{array}{l}\text { Yu lin cheng bei } \\
\left(38^{\circ} 21.610^{\prime} \mathrm{N}, 109^{\circ} 41.978^{\prime} \mathrm{E}\right)\end{array}$ & $\begin{array}{l}\text { top few } \mathrm{cm} \text { of } \\
\text { loess section }\end{array}$ & $\begin{array}{c}0.02 \pm 0.04 \\
(n=16)\end{array}$ & $63-90$ & $\begin{array}{c}0.37 \pm 0.12 \\
(n=4)\end{array}$ & $\begin{array}{c}1.65 \pm 0.12 \\
(n=4)\end{array}$ & $\begin{array}{c}2.0 \pm 0.2 \\
(n=4)\end{array}$ & $\begin{array}{c}7.3 \pm 0.6 \\
(n=4)\end{array}$ \\
\hline D13 & Xi'an & $\begin{array}{l}\text { superficial dust } \\
\text { from top of } \\
\text { building }\end{array}$ & $\begin{array}{l}0.17 \pm 0.07 \\
(n=18)\end{array}$ & $63-90$ & $\begin{array}{l}0.19 \pm 0.02 \\
(n=3)\end{array}$ & $\begin{array}{l}1.88 \pm 0.06 \\
(n=7)\end{array}$ & $\begin{array}{c}1.6 \pm 0.4 \\
(n=6)\end{array}$ & $\begin{array}{c}6.5 \pm 1.3 \\
(n=6)\end{array}$ \\
\hline \multirow{2}{*}{ CB } & \multirow{2}{*}{$\begin{array}{l}\text { Collected during } \sim 200 \mathrm{~km} \\
\text { transect from Xi'an to Luo- } \\
\text { chuan }\end{array}$} & \multirow{2}{*}{$\begin{array}{l}\text { superficial dust } \\
\text { from car bump- } \\
\text { er }\end{array}$} & $\begin{array}{c}0.36 \pm 0.04(1) \\
(n=11)\end{array}$ & $4-11$ & $\begin{array}{c}0.40 \pm 0.02 \\
(n=4)\end{array}$ & $\begin{array}{l}1.91 \pm 0.09 \\
(n=4)\end{array}$ & $\begin{array}{l}7.5 \pm 0.5 \\
(n=6)\end{array}$ & $\begin{array}{c}15.6 \pm 0.5 \\
(n=6)\end{array}$ \\
\hline & & & $\begin{array}{c}0.109 \pm 0.004 \\
(n=14)\end{array}$ & $36-50$ & & & & \\
\hline \multirow[t]{2}{*}{ TPU } & $\begin{array}{l}\text { Beijing (building Peking } \\
\text { University) }\end{array}$ & $\begin{array}{l}\text { superficial dust } \\
\text { from top of } \\
\text { building }\end{array}$ & $\begin{array}{c}0.24 \pm 0.03 \\
(n=15)\end{array}$ & $4-11$ & $\begin{array}{l}0.15 \pm 0.02 \\
(n=3)\end{array}$ & $\begin{array}{l}1.49 \pm 0.02 \\
(n=3)\end{array}$ & $\begin{array}{l}1.97 \pm 0.07 \\
(n=6)\end{array}$ & $\begin{array}{c}5.3 \pm 0.2 \\
(n=3)\end{array}$ \\
\hline & & Average \pm s.e. & $0.22 \pm 0.11^{(2)}$ & & $0.42 \pm 0.13$ & $2.0 \pm 0.2$ & $4.1 \pm 1.1$ & $10.5 \pm 2.3$ \\
\hline
\end{tabular}

Table 2. The different SAR-IRSL measurement protocols used in this study.

\begin{tabular}{|c|c|c|c|}
\hline Step & $\mathrm{IR}_{50}$ & plRIR225 & pIRIR 290 \\
\hline$\overline{1}$ & Dose & Dose & Dose \\
\hline 2 & Preheat $\left(125^{\circ} \mathrm{C}\right.$ to $325^{\circ} \mathrm{C}$ for $\left.60 \mathrm{~s}\right)$ & Preheat $\left(250^{\circ} \mathrm{C}\right.$ for $\left.60 \mathrm{~s}\right)$ & Preheat $\left(320^{\circ} \mathrm{C}\right.$ for $\left.60 \mathrm{~s}\right)$ \\
\hline 3 & - & IRSL, 100 s at $50^{\circ} \mathrm{C}$ & IRSL, 200 s at $50^{\circ} \mathrm{C}$ \\
\hline 4 & IRSL, 100 or 300 s at $50^{\circ} \mathrm{C} \rightarrow \mathrm{L}_{x}$ & IRSL, 100 s at $225^{\circ} \mathrm{C} \rightarrow \mathrm{L}_{x}$ & IRSL, 200 s at $290^{\circ} \mathrm{C} \rightarrow \mathrm{L}_{x}$ \\
\hline 5 & Test dose & Test dose & Test dose \\
\hline 6 & Preheat $\left(125^{\circ} \mathrm{C}\right.$ to $325^{\circ} \mathrm{C}$ for $\left.60 \mathrm{~s}\right)$ & Preheat $\left(250^{\circ} \mathrm{C}\right.$ for $\left.60 \mathrm{~s}\right)$ & Preheat $\left(320^{\circ} \mathrm{C}\right.$ for $\left.60 \mathrm{~s}\right)$ \\
\hline 7 & - & IRSL, 100 s at $50^{\circ} \mathrm{C}$ & IRSL, 200 s at $50^{\circ} \mathrm{C}$ \\
\hline 8 & IRSL, 100 or 300 s at $50^{\circ} \mathrm{C} \rightarrow \mathrm{T}_{\mathrm{x}}$ & IRSL, $100 \mathrm{~s}$ at $225^{\circ} \mathrm{C} \rightarrow \mathrm{T}_{\mathrm{x}}$ & IRSL, 200 s at $290^{\circ} \mathrm{C} \rightarrow \mathrm{T}_{\mathrm{x}}$ \\
\hline 9 & IRSL, 40 s at $290^{\circ} \mathrm{C}$ & IRSL, 40 s at $290^{\circ} \mathrm{C}$ & IRSL, 100 s at $325^{\circ} \mathrm{C}$ \\
\hline 10 & Return to step 1 & Return to step 1 & Return to step 1 \\
\hline
\end{tabular}


(Thomsen et al., 2008). Consequently, the ages are less dependent on the assumptions included in the fading correction models. This has been confirmed by Buylaert et al. (2009) for sand-sized K-feldspar grains and for polymineral fine-grains extracted from European loess by Thiel et al. (2011a). Here we test this conclusion for the first time for polymineral fine-grains extracted from Chinese loess by comparing the observed natural IRSL signal with the dose response curve for the three signals discussed in this paper, IRSL at $50^{\circ} \mathrm{C}\left(\mathrm{IR}_{50}\right)$, IRSL at $225^{\circ} \mathrm{C}$ following $\mathrm{IR}_{50}\left(\mathrm{pIRIR}_{225}\right)$ and IRSL at $290^{\circ} \mathrm{C}$ following $\mathrm{IR}_{50}\left(\mathrm{pIRIR}{ }_{290}\right)$ using the protocols given in Table 2 and sample A42 ( 900 ka). This sample has a predicted burial dose for polymineral fine-grains (feldspar) of $\sim 3 \mathrm{kGy}$ taking into account the dose rate to polymineral fine-grains for this sample of $3.62 \pm 0.16 \mathrm{~Gy} / \mathrm{ka}$ (Buylaert et al., 2007). This dose is well beyond the expected saturation dose for this material.

Fig. 1 shows the three natural signals interpolated onto their respective dose response curves. As expected the $\mathrm{IR}_{50}$ signal is only $56 \%$ of the laboratory saturation IRSL intensity and predicts a finite dose of $\sim 400 \mathrm{~Gy}$. The pIRIR $_{225}$ is $73 \%$ of the saturation value and the pIRIR 290 is indistinguishable from saturation with an intensity of

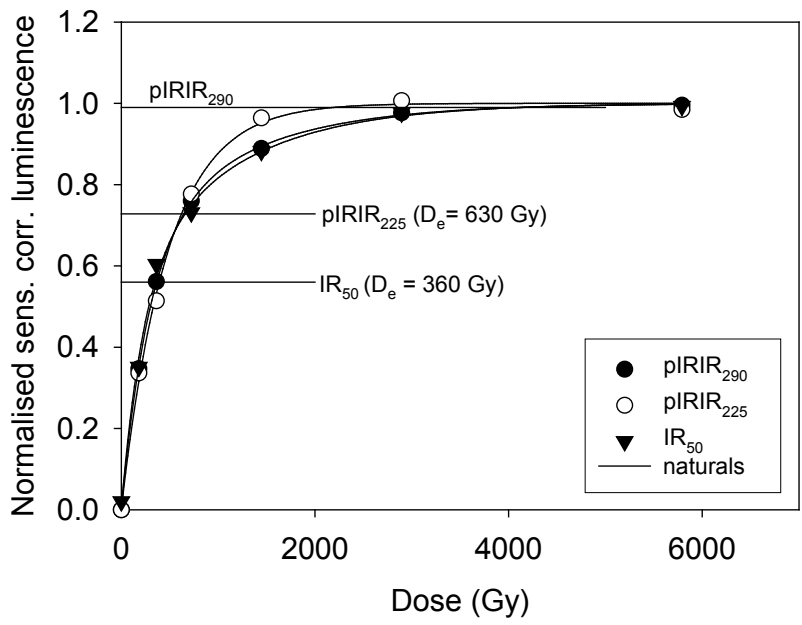

Fig. 1. $I R_{50}$, pIRIR 225 and $p I R I R_{290}$ SAR dose response curves for polymineral fine-grains extracted from sample A42 collected in the $L 9$ loess layer at the Luochuan section (well below the Brunhes/Matuyama boundary) (Buylaert et al., 2007). This sample has an expected age of $\sim 900 \mathrm{ka}$ and is confidently expected to be in saturation. The pIRIR 290 and $I_{50}$ data were fitted with a double saturating exponential function of the form $y=a(1-\exp (-b x))+c(1-\exp (-d x))$ and the pIRIR 225 data with a single saturating exponential function $y=a(1-\exp (-$ bx)). The $L_{x} / T_{x}$ values were normalised to the fitted saturation values (' $a+c$ ' for the double saturating exponentials and 'a' for the single exponential function). Taking a light level of $86 \%$ of saturation as the practical upper limit to give a resolvable dose (Wintle and Murray, 2006) we derive upper dose limits of $1300 \mathrm{~Gy}$ (IR50), $950 \mathrm{~Gy}$ (pIRIR225) and $1170 \mathrm{~Gy}\left(p / R I R_{290}\right)$. The sensitivity corrected natural luminescence levels are shown as horizontal lines and the corresponding $D_{e}$ values are given between brackets. One aliquot was measured per protocol.
$99 \%$. These data clearly support the suggestion that pIRIR signals are less prone to fading than the $\mathrm{IR}_{50}$ and indeed suggest that the pIRIR $_{290}$ may not fade significantly. A similar observation has been reported by Thiel et al. (2011a) for $\mathrm{IR}_{50}$ and pIRIR 290 for European loess.

Previous work has shown that the $\operatorname{pIRIR}_{225}$ and pIRIR $_{290}$ residual doses (using modern coarse grained $\mathrm{K}$-feldspars and laboratory bleached fine-grains respectively) tend to be greater than those observed using the $\mathrm{IR}_{50}$ signal (Thomsen et al., 2008; Buylaert et al., 2009; Thiel et al., 2011a). The next section examines whether these preliminary observations apply to polymineral finegrains extracted from Chinese loess.

\section{LUMINESCENCE CHARACTERISTICS AND $D_{\mathrm{e}}$ ESTIMATES}

Fig. 2 illustrates some of the luminescence characteristics of Chinese loess using sample D9. As is to be expected for such a young sample, both the corrected natural OSL and IRSL signals lie on the linear part of the dose response curve. The natural signal from quartz is clearly much smaller than the regenerated signal compared to any of the three feldspar signals (i.e. $I_{50}$, pIRIR $_{225}$ and pIRIR 290 ; see top left insets Fig. 2). The $\mathrm{D}_{\mathrm{e}}$ 's derived from the different signals are summarised for all the samples in Table 1 .

To demonstrate that the SAR protocols used here (outlined in Table 2) are applicable to these samples several checks can be made. As is common for feldspar measurements, recycling ratios are very close to unity for all samples $\left(0.988 \pm 0.009, \mathrm{n}=9, \mathrm{IR}_{50 \mathrm{ph}=150^{\circ} \mathrm{C}} ; 0.995 \pm 0.010\right.$, $\mathrm{n}=27, \mathrm{IR}_{50, \mathrm{ph}=250^{\circ} \mathrm{C}} ; 1.00 \pm 0.01, \mathrm{n}=35, \mathrm{pIRIR}{ }_{225} ; 0.99 \pm 0.02$, $\mathrm{n}=32$, pIRIR ${ }_{290} ; \mathrm{n}$ denotes the number of aliquots that contribute to the quoted averages from different samples);

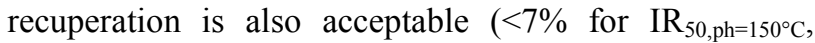
$<5 \%$ for $\mathrm{IR}_{50, \mathrm{ph}=250^{\circ} \mathrm{C},}<7 \%$ for $\mathrm{pIRIR}_{225}$ and $<4 \%$ for pIRIR ${ }_{290}$ ). The most complete laboratory test for any SAR protocol is to carry out a dose recovery test (Wallinga et al., 2000) to check whether a laboratory dose given before any heat treatment can be accurately measured. The advantage of working with modern dust samples is that we can add a large laboratory dose on top of the relatively small natural dose which allows us to avoid the bleaching step that would be necessary to remove the natural luminescence signal. In this experiment we have added a laboratory dose of 45 Gy to the natural samples and measured the dose with the SAR protocols outlined in Table 2. Between 2 and 8 aliquots were measured per measurement protocol for each of the 5 samples used. After subtraction of the natural $D_{e}$ (Table 1) from the measured dose, dose recovery ratios are consistent with unity for all protocols used. The mean values

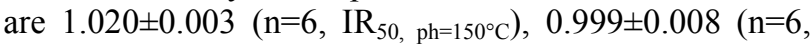
$\left.\mathrm{IR}_{\left.50, \mathrm{ph}=250^{\circ} \mathrm{C}\right), 1.01 \pm 0.03(\mathrm{n}=28, \mathrm{pIRIR}} 225\right)$ and $1.01 \pm 0.05$ $(\mathrm{n}=23$, pIRIR 290$)$. It seems that all the SAR protocols 

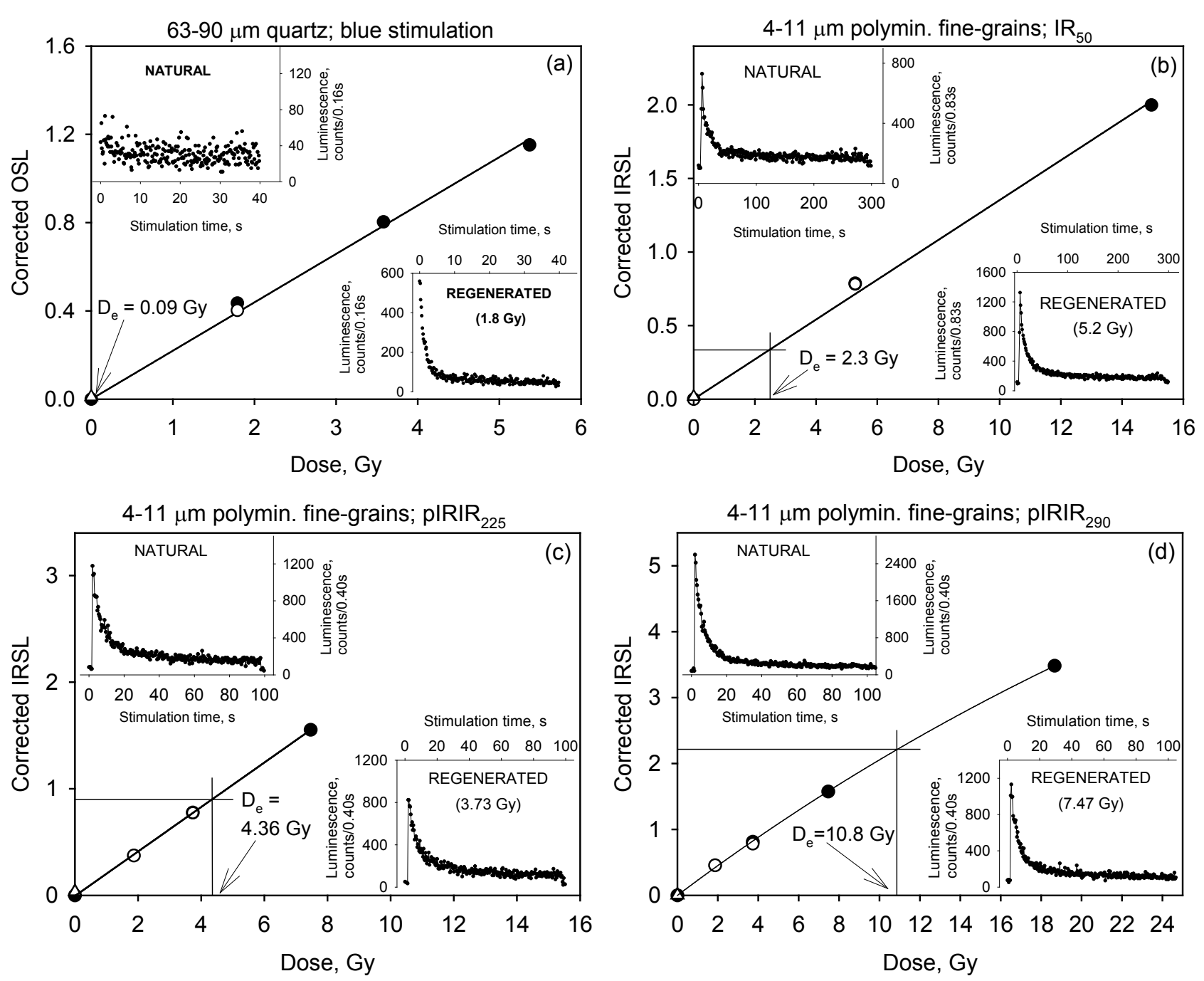

Fig. 2. Representative dose response curves of sample $D 9$ for the different signals under investigation. (a) quartz $O S L$, (b) $I R 50$ (preheat=250 $\left.{ }^{\circ} \mathrm{C} / 60 \mathrm{~s}\right)$, (c) pIRIR 225 , (d) pIRIR290. Recycled points and zero dose (recuperation) points are shown as open circles and triangles respectively. The insets show natural (top left) and regenerated (bottom right) decay curves.

outlined in Table 2 are able to accurately measure a laboratory dose prior to any heat treatment. For completeness, the quartz OSL dose recovery ratio for sample D9 (dose of 34 Gy on top of natural aliquots) is $0.96 \pm 0.02$ $(n=3)$.

It is interesting to note that for the quartz OSL measurements only one sample (D10) yields a $\mathrm{D}_{\mathrm{e}}$ indistinguishable from zero. This is surprising given the aeolian nature of deposition of these samples. The coarser grain fractions also seem to be better bleached than the 4-11 $\mu \mathrm{m}$ fractions. This is consistent with what has been reported for fluvial sediments (Olley et al., 1998; Wallinga, 2002; Vandenberghe et al., 2007). Nevertheless, for the purpose of comparison with the polymineral fine-grain feldspar doses the quartz doses are small enough (of the order of a few tens to hundreds of mGy) to represent well-bleached sediment.
The doses recorded by $\mathrm{IR}_{50}$ (both $\mathrm{ph}=150^{\circ} \mathrm{C}$ and $\mathrm{ph}=250^{\circ} \mathrm{C}$ ), $\mathrm{pIRIR}_{225}$ and $\mathrm{pIRIR}_{290}$ are plotted for all samples against their quartz OSL $\mathrm{D}_{\mathrm{e}}$ in Fig. 3. On average the apparent dose follows the pattern: $I_{50}$ $\left(\mathrm{ph}=150^{\circ} \mathrm{C}\right)<\mathrm{IR}_{50}\left(\mathrm{ph}=250^{\circ} \mathrm{C}\right)<\mathrm{pIRIR}_{225}<\mathrm{pIRIR}_{290}$. Only two samples measured with a low $150^{\circ} \mathrm{C}$ preheat and with IR stimulation at $50^{\circ} \mathrm{C}$ are consistent with the slope predicted from the difference in dose rate between coarse quartz grains and polymineral fine-grains, the rest show apparent overestimation of feldspar doses (see caption to Fig. 3). In the next section we address the question whether this apparent overestimation arises because of incomplete bleaching or transfer of charge from optically-insensitive thermally-shallow traps to the optically-sensitive traps during preheating. 


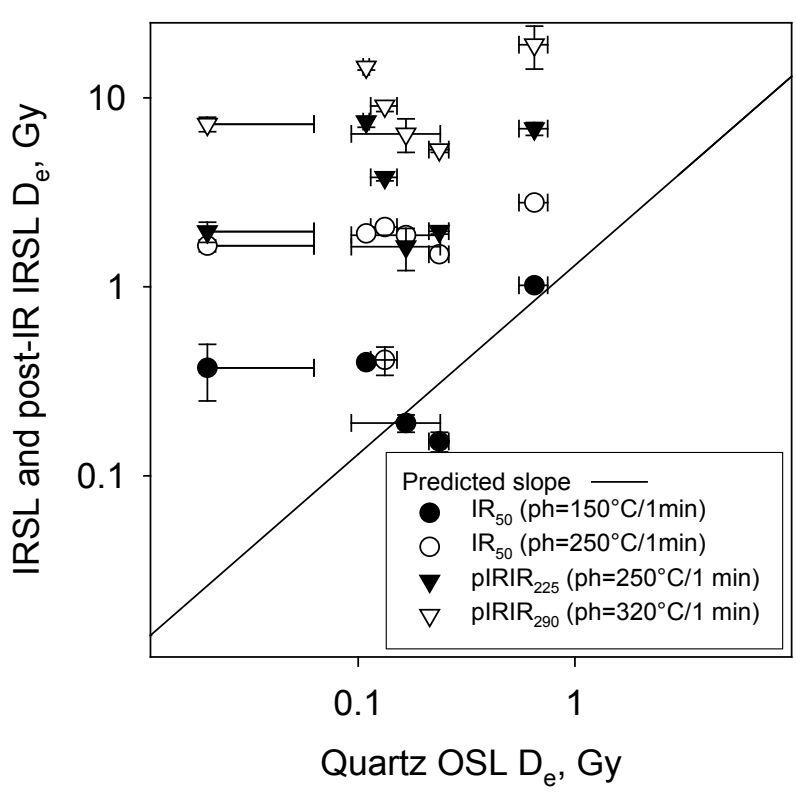

Fig. 3. Equivalent dose estimates derived from the $\mathbb{I R}_{50}$ (both for preheats of $150^{\circ} \mathrm{C}$ and $250^{\circ} \mathrm{C}$ ), pIRIR 225 and pIRIR 290 protocols plotted against those from quartz OSL for all modern samples used. A minimum of three aliquots was used to determine the average $D_{e}$ values and error bars represent 1 standard error. The solid line represents the predicted slope of this relationship for well-bleached material; it is based on the difference in dose rate between coarse quartz grains and polymineral fine-grains. The average ratio of the polymineral fine-grain to coarse grained quartz dose rates for the loess samples in Buylaert et al. (2007; their Table S1) is 1.290 $\pm 0.003(n=9)$. This value was used to plot the predicted slope.

\section{INCOMPLETE BLEACHING OR THERMAL TRANSFER?}

A contribution from charge thermally transferred to the IRSL trap(s) during preheating can cause an apparent dose to be measured in a sample expected to contain a "zero dose" or at least a very small dose (Aitken, 1998). The presence of thermal transfer in polymineral finegrains has already been reported by Rees-Jones and Tite (1994). Whereas in principle it would be possible to keep the preheat low for the $\mathrm{IR}_{50}$ signal, a difficulty in post-IR IRSL dating is that it is necessary to use a preheat that is equal to or higher than the stimulation temperature (to avoid the influence of a thermoluminescence signal on the post-IR IRSL signal of interest). These preheats are typically $20-30^{\circ} \mathrm{C}$ higher than the post-IR IR stimulation temperature (Table 2).

Two superficial dust samples (TPU and CB) were used to check the contribution of thermal transfer in our data (Fig. 3 and Table 1). For the $I_{50}$ signal the $D_{e}$ values measured using polymineral fine-grains from these two samples are shown in Fig. 4 as a function of storage for $60 \mathrm{~s}$ at the given preheat temperatures. At low temperatures the $\mathrm{D}_{\mathrm{e}}$ is very small (although still finite), but it increases to

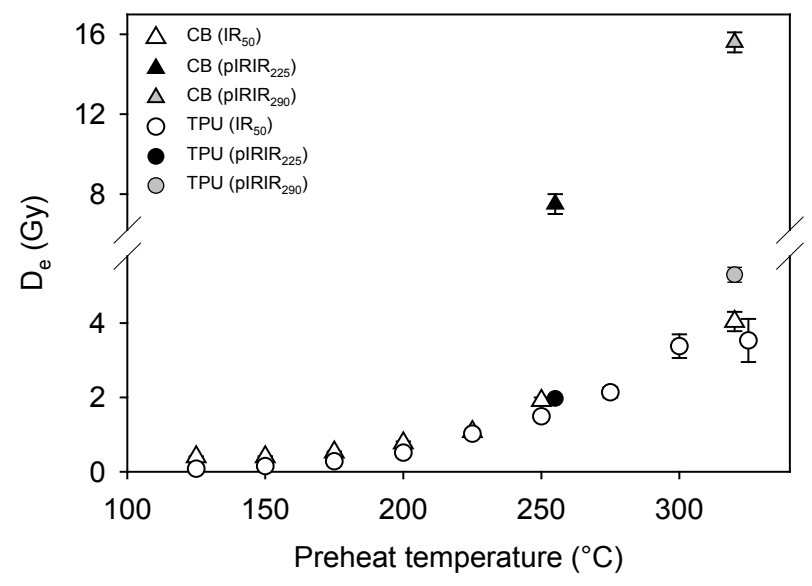

Fig. 4. Apparent $I R_{50}, p / R R_{225}$ and $p I R I R_{290} D_{e}$ values as a function of preheat temperature (storage $60 \mathrm{~s}$ ) for two superficial Chinese dust samples. Three aliquots were measured per preheat temperature and error bars represent one standard error. Due to a lack of material the plot for the IR $R_{50}$ signal of sample $C B$ ends at $250^{\circ} \mathrm{C}$.

$\geq 1.5$ Gy for a preheat temperature of $250^{\circ} \mathrm{C}$. This smooth increase with temperature suggests a contribution from transfer from thermally-shallow light-insensitive traps to the IR-sensitive dosimetry trap(s) for preheats $\geq 150^{\circ} \mathrm{C}$. From the difference in dose estimates at low temperatures, it also appears that the Beijing dust sample (TPU) is better bleached than the car bumper (CB) sample. For the TPU sample the pIRIR 225 (preheat of $250^{\circ} \mathrm{C}$ ) and pIRIR $_{290}$ (preheat of $320^{\circ} \mathrm{C}$ ) signal seem to closely follow the trend of the $\mathrm{IR}_{50}$ thermal transfer curve. Both signals also appear to be nearly as well-bleached as the $\mathrm{IR}_{50}$ signal. For the $\mathrm{CB}$ sample the pIRIR 225 and pIRIR 290 signals seem to be less well-bleached than the $\mathrm{IR}_{50}$ signal; the dose difference for pIRIR $_{225}$ is $\sim 6$ Gy and for pIRIR 290 of $\sim 10$ Gy respectively.

The question now arises whether one can, in order to avoid thermal transfer, use a low temperature $\left(<200^{\circ} \mathrm{C}\right)$ preheat when dating loess with IRSL measured at $50^{\circ} \mathrm{C}$.

\section{CAN WE USE A LOW TEMPERATURE PRE- HEAT TO DATE LOESS USING IRSL AT $50^{\circ} \mathrm{C}$ ?}

A Chinese loess sample (A7) with a quartz OSL age of 29.0 $1.0 \mathrm{ka}$ (Buylaert et al., 2008) is used to check whether low temperature preheats can be used for dating with the IRSL measured at $50^{\circ} \mathrm{C}$. In this age range quartz OSL dating provides suitable age control (the quartz $\mathrm{D}_{\mathrm{e}}$ is $92 \pm 2$ Gy). This sample was also dated using $\mathrm{pIRIR}_{225}$ and $\mathrm{pIRIR}_{290}$. Anomalous fading rates ( $g$-values; Aitken, 1985) were measured using SAR on the same aliquots that were used for $\mathrm{D}_{\mathrm{e}}$ determinations (Auclair et al., 2003). The results are shown in Fig. 5 and Table 3 gives the individual $\mathrm{D}_{\mathrm{e}}$ values, fading rates and ages for preheat temperatures of $150^{\circ} \mathrm{C}, 250^{\circ} \mathrm{C}$ and $320^{\circ} \mathrm{C}$.

The fading corrected $\mathrm{IR}_{50}$ age plateau, measured between preheats of $125^{\circ} \mathrm{C}$ and $275^{\circ} \mathrm{C}$, shows a weak but 
clear overall rising trend. The low $\mathrm{IR}_{50}$ ages at lower $\left(<200^{\circ} \mathrm{C}\right)$ preheat temperatures are almost certainly caused by a contribution from a thermally unstable signal induced during laboratory dosing that is not removed during lower temperature preheating; the increase in $\mathrm{D}_{\mathrm{e}}$ with increasing temperature is $\sim 25$ Gy $(\sim 22 \%$ of the average high temperature dose), much larger than the ther-

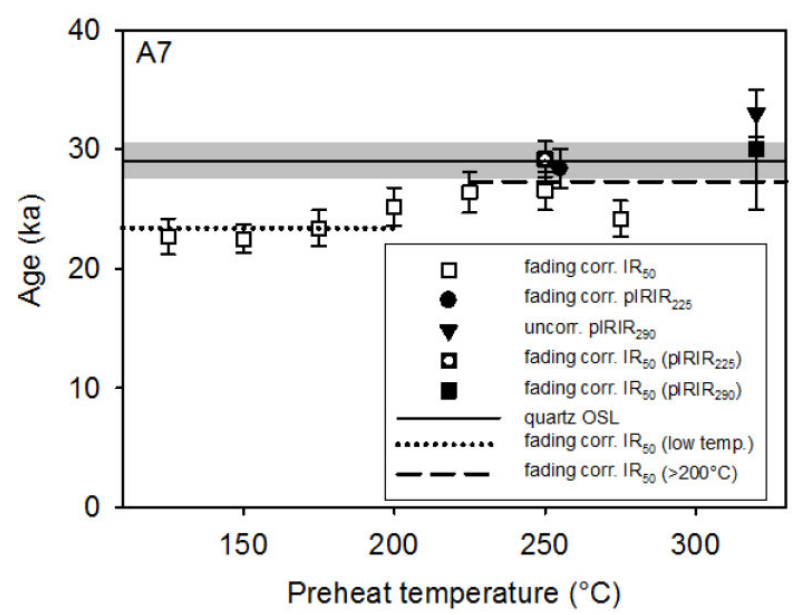

Fig. 5. Age-preheat plot of the IRSL and post-IR IRSL measurements for an older Chinese loess sample (A7) previously dated using quartz OSL by Buylaert et al. (2008). The solid line represent the quartz OSL age ( \pm 1 s.e. shown as a grey band). The residual doses of the $C B$ sample were subtracted from the $D_{e}$ values (Table 1). From the $I R_{50} D_{e}$ values the residual doses were subtracted based on the thermal transfer curve of the CB sample in Fig. 4. The IR 50 and pIRIR 225 ages were corrected using the model of Huntley and Lamothe (2001). As

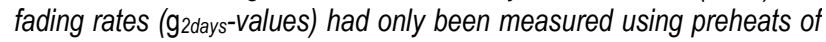
$150^{\circ} \mathrm{C}$ and $250^{\circ} \mathrm{C}$ for the $I R_{50}$ signal, the fading rates for intermediate temperatures of the $I R_{50}$ measurements were interpolated $\left(175^{\circ} \mathrm{C}\right.$, $200^{\circ} \mathrm{C}$ and $\left.225^{\circ} \mathrm{C}\right)$ or extrapolated $\left(125^{\circ} \mathrm{C}\right.$ and $\left.275^{\circ} \mathrm{C}\right)$. The average fading corrected IR 50 ages for low $\left(125-200^{\circ} \mathrm{C}\right)$ and high temperatures $\left(225-320^{\circ} \mathrm{C}\right)$ are shown as dotted and dashed lines respectively. Three aliquots were measured at each temperature and error bars represent one standard error. mally transferred dose for $\mathrm{IR}_{50}$ in Fig. 4 (which only reaches $\sim 2$ Gy at $275^{\circ} \mathrm{C}$ ). For preheat temperatures $>200^{\circ} \mathrm{C}$ the fading corrected $\mathrm{IR}_{50}$ results are in agreement with the quartz age. It is worth noting that the rising trend in the fading corrected $\mathrm{IR}_{50}$ age with temperature is somewhat less pronounced than the trend in dose because of a lower fading rate at higher temperatures; the difference between fading corrected $\mathrm{IR}_{50}$ ages at $150^{\circ} \mathrm{C}$ and at $250^{\circ} \mathrm{C}$ is $\sim 15 \%$ (still too large to be explained entirely by thermal transfer).

The fading rates of both pIRIR signals are lower than the fading rates measured at $50^{\circ} \mathrm{C}$; this is consistent with previous observations (e.g. Buylaert et al., 2009). It is interesting to note that the pIRIR 225 and pIRIR 290 fading rates are not significantly different from each other. There is some published evidence that pIRIR $_{225}$ ages do indeed need fading correction (Buylaert et al., 2009, Thiel et al., $2011 b)$ and that pIRIR 290 ages do not need fading correction (Thiel et al., 2011a; Thiel et al., 2011c; Thomsen et al., 2011); the latter observation is further supported by the data of Fig. 1, in which the natural IR signal from a pIRIR $_{225}$ protocol is only $\sim 73 \%$ of the laboratory saturation value, whereas the $\mathrm{pIRIR}_{290}$ signal is $99 \%$ of laboratory saturation. Both corrected pIRIR 225 and uncorrected pIRIR $_{290}$ (within 2 sigma) ages are in agreement with the quartz age and with the fading corrected $\mathrm{IR}_{50}$ ages measured as part of the post-IR IRSL measurement protocols (i.e. with $250^{\circ} \mathrm{C}$ and $320^{\circ} \mathrm{C}$ preheats) . For completeness we have also fading corrected the pIRIR ${ }_{290}$ age; the resulting $36 \pm 3 \mathrm{ka}$ seems to overestimate the expected quartz age (Table 3). This further supports the suggestion above that the pIRIR $_{290}$ signal should not be corrected for any apparent laboratory fading, and indicates that the measured (very low) fading rate for pIRIR ${ }_{290}$ signal may be a laboratory artefact.

The observation that the pIRIR ages for this sample are in agreement with the quartz age is encouraging. However, more samples, with independent age control are needed before we can confidently state that this dating

Table 3. Summary of IRSL and post-IR IRSL measurements for sample A7 of the Zhongjiacai site previously dated using quartz OSL by Buylaert et al. (2008). The g-values were normalised to a measurement delay time of 2 days after irradiation (i.e. g2days, Huntley and Lamothe, 2001). Three aliquots were measured per treatment.

\begin{tabular}{|c|c|c|c|c|c|c|c|}
\hline Code & & $\begin{array}{c}\text { Dose rate (2) } \\
\text { (Gy/ka) }\end{array}$ & $\begin{array}{l}D_{e}(3) \\
(G y)\end{array}$ & $\begin{array}{c}g_{2 \text { days }} \\
\text { (\%/decade) }\end{array}$ & $\begin{array}{l}\text { Uncorrected age } \\
\text { (ka) }\end{array}$ & $\begin{array}{c}\text { Corrected age }{ }^{(4)} \\
\text { (ka) }\end{array}$ & $\begin{array}{l}\text { Quartz age (1) } \\
\text { (ka) }\end{array}$ \\
\hline \multirow[t]{6}{*}{$\bar{A} 7^{(1)}$} & $\mathrm{IR}_{50}\left(\mathrm{Ph}: 150^{\circ} \mathrm{C} / 60 \mathrm{~s}\right)$ & $4.08 \pm 0.21$ & $61.9 \pm 0.1$ & $4.13 \pm 0.10$ & $15.2 \pm 0.8$ & $22.5 \pm 1.2$ & $29.0 \pm 1.4$ \\
\hline & $\mathrm{IR}_{50}\left(\mathrm{Ph}: 250^{\circ} \mathrm{C} / 60 \mathrm{~s}\right)$ & " & $87 \pm 2$ & $2.4 \pm 0.4$ & $21.3 \pm 1.2$ & $27 \pm 2$ & - \\
\hline & $\mathrm{pIRIR}_{225}\left(\mathrm{Ph}: 250^{\circ} \mathrm{C} / 60 \mathrm{~s}\right)$ & “ & $103 \pm 2$ & $1.33 \pm 0.14$ & $25.2 \pm 1.4$ & $28 \pm 2$ & - \\
\hline & $\mathrm{pIRIR}_{290}\left(\mathrm{Ph}: 320^{\circ} \mathrm{C} / 60 \mathrm{~s}\right)$ & “ & $135 \pm 3$ & $1.0 \pm 0.8$ & $33 \pm 2$ & $36 \pm 3$ & - \\
\hline & $\mathrm{IR}_{50}$ from $\mathrm{pIRIR} 225$ & “ & $86.1 \pm 0.4$ & $3.44 \pm 0.03$ & $21.1 \pm 1.1$ & $29 \pm 2$ & - \\
\hline & $\mathrm{IR}_{50}$ from plRIR 290 & " & $87 \pm 5$ & $3.9 \pm 1.1$ & $21 \pm 2$ & $30 \pm 5$ & - \\
\hline
\end{tabular}

(1) See Buylaert et al. (2008)

(2) Dose rate to polymineral fine-grains was calculated using the radionuclide concentrations and water content given in Buylaert et al. (2008). An avalue of 0.08 to allow for the lower luminescence efficiency of alpha compared to beta and gamma radiation was used in the calculation (ReesJones, 1995).

(3) Residual doses equal to those measured for the CB sample at the relevant preheat temperatures (Fig. 4) were subtracted from the $D_{e}$

(4) The fading correction was carried out following the model of Huntley and Lamothe (2001) 
approach always yields accurate results in Chinese loess. Nevertheless, we can conclude that although low preheat temperatures may avoid or minimise thermal transfer, this is probably at the expense of an increasingly significant contribution from a thermally-shallow unstable signal which leads to a significant underestimate of dose. Similar conclusions were reported using a different (multiple aliquot) protocol by Li and Wintle (1992).

\section{CONCLUSIONS}

Using a set of modern/young dust samples from China the residual doses measured with $\mathrm{IR}_{50}$ and two post-IR IRSL protocols (pIRIR 225 and pIRIR 290 ) have been measured; these give doses in the range up to $\sim 20 \mathrm{~Gy}$. Quartz OSL doses (all $<650 \mathrm{mGy}$ ) are used to confirm that our samples are indeed modern/very young. As has been shown by others, there is clear evidence for thermal transfer in IRSL signals from polymineral fine-grains; this results from the preheating of the sample prior to IRSL measurement. From our data it seems that thermal transfer is present in $\mathrm{IR}_{50}$ signals but also, and to a larger degree, in the post-IR IRSL signals. On average the residual doses recorded in modern/very young samples, presumably mainly arising from thermal transfer effects, amount to $2.0 \pm 0.2$ Gy for $\mathrm{IR}_{50}, 4.1 \pm 1.1 \mathrm{~Gy}$ for $\mathrm{pIRIR}_{225}$ and $10 \pm 2$ Gy for pIRIR 290 . Whereas in principle a low temperature preheat could be used to avoid thermal transfer during $\mathrm{IR}_{50}$ measurements this seems unadvisable for the post-IR IRSL measurements because of the then unavoidable TL contribution arising from the high temperature second IR stimulation. Based on a measurement of the dependence of age on preheat for a relatively old $(\sim 30 \mathrm{ka})$ loess sample, we show that it is not actually advisable to use a low preheat temperature for the $\mathrm{IR}_{50}$ signal either; for preheat temperatures $<200^{\circ} \mathrm{C}$ at least part of the $\mathrm{IR}_{50}$ signal appears to be made up of a thermally unstable component. The apparent residual doses measured on modern material using post-IR IRSL suggests that it seems prudent not to apply post-IR IRSL dating to Chinese loess samples for which residual doses up to $\sim 20 \mathrm{~Gy}$ are likely to be significant.

\section{ACKNOWLEDGEMENTS}

Financial support from the Nordic Centre of Excellence programme of the Joint Committee of Nordic Natural Science Research Councils is gratefully acknowledged. DV is a postdoctoral fellow of the Research Foundation - Flanders (FWO - Vlaanderen). Liping Zhou, Jintang Qin, and Yali Zhou are thanked for help during sample collection. The technical assistance of Jochem Temmerman, Nicole Selen and Gilles Velghe (Ghent University) is very much appreciated. Saiko Sugisaki is thanked for help with the luminescence measurements, and Ann Wintle for comments on an earlier draft of this paper.

\section{REFERENCES}

Aitken MJ, 1985. Thermoluminescence Dating. London, Academic Press: 359pp.

Aitken MJ, 1998. An Introduction to Optical Dating. London, Oxford University Press: 267pp.

Auclair M, Lamothe M and Huot S, 2003. Measurement of anomalous fading for feldspar IRSL using SAR. Radiation Measurements 37(4-5): 487-492, DOI 10.1016/S1350-4487(03)00018-0.

Auclair M, Lamothe M, Lagroix F and Banerjee SK, 2007. Luminescence investigations of loess and tephra from Halfway House section, Central Alaska. Quaternary Geochronology 2(1-4): 34-38, DOI 10.1016/j.quageo.2006.05.009.

Banerjee D, Murray AS, Bøtter-Jensen L and Lang A, 2001. Equivalent dose determination from a single aliquot of polymineral fine grains. Radiation Measurements 33(1): 73-94, DOI 10.1016/S1350-4487(00)00101-3.

Blair MW, Yukihara EG and McKeever SWS, 2005. Experiences with single-aliquot OSL procedures using coarse-grain feldspars. $R a$ diation Measurements 39(4): 361-374, $\quad$ DOI 10.1016/j.radmeas.2004.05.008.

Buylaert JP, Vandenberghe D, Murray AS, Huot S, De Corte F and Van den haute P, 2007. Luminescence dating of old (>70 ka) Chinese loess: a comparison of single-aliquot OSL and IRSL techniques. Quaternary Geochronology 2(1-4): 9-14, DOI 10.1016/j.quageo.2006.05.028.

Buylaert JP, Murray AS, Vandenberghe D, Vriend M, De Corte F and Van den haute P, 2008. Optical dating of Chinese loess using sandsized quartz: Establishing a time frame for Late Pleistocene climate changes in the western part of the Chinese Loess Plateau. Quaternary Geochronology 3(1-2): 99-113, DOI 10.1016/j.quageo.2007.05.003.

Buylaert JP, Murray AS, Thomsen KJ and Jain M, 2009. Testing the potential of an elevated temperature IRSL signal from K-feldspar. Radiation Measurements 44(5-6): 560-565, DOI 10.1016/j.radmeas.2009.02.007.

Bøtter-Jensen L, Andersen CE, Duller GAT and Murray AS, 2003. Developments in radiation, stimulation and observation facilities in luminescence measurements. Radiation Measurements 37(4-5): 535-541, DOI 10.1016/S1350-4487(03)00020-9.

Frechen M, 1999. Luminescence dating of loessic sediments from the Loess plateau, China. Geologische Rundschau 87(4): 675-684, DOI $10.1007 / \mathrm{s} 005310050239$.

Frechen M and Dodonov AE, 1999. Loess chronology of the Middle and Upper Pleistocene in Tadjikistan. Geologische Rundschau 87(1): 2-20, DOI 10.1007/s005310050185.

Frechen M, Schweitzer U and Zander A, 1996. Improvements in sample preparation for the fine grain technique. Ancient TL 14: 15-17.

Godfrey-Smith DI, Huntley DJ and Chen W-H, 1988. Optical dating studies of quartz and feldspar sediment extracts. Quaternary Science Reviews 7(3-4): 373-380, DOI 10.1016/0277-3791(88)900327.

Huntley DJ and Lamothe M, 2001. Ubiquity of anomalous fading in Kfeldspars and the measurement and correction for it in optical dating. Canadian Journal of Earth Sciences 38(7): 1093-1106, DOI 10.1139/e01-013.

Lai ZP, 2010. Chronology and the upper dating limit for loess samples from Luochuan section in the Chinese Loess Plateau using quartz OSL SAR protocol. Journal of Asian Earth Sciences 37(2): 176185, DOI 10.1016/j.jseaes.2009.08.003.

Lang A, Hatté C, Rousseau D-D, Antoine P, Fontugne M, Zöller L and Hambach U, 2003. High-resolution chronologies for loess: comparing AMS ${ }^{14} \mathrm{C}$ and optical dating results. Quaternary Science Reviews 22(10-13): 953-959, DOI 10.1016/S0277-3791(03)000350.

Li SH and Wintle AG, 1992. A global view of the stability of luminescence signals from loess. Quaternary Science Reviews 11(1-2): 133-137, DOI 10.1016/0277-3791(92)90054-C.

Lian OB and Huntley DJ, 1999. Optical dating studies of postglacial aeolian deposits from the south-central interior of British Colum- 
bia, Canada. Quaternary Science Reviews 18(13): 1453-1466, DOI 10.1016/S0277-3791(98)00085-7.

$\mathrm{Lu}$ YC, Wang XL and Wintle AG, 2007. A new OSL chronology for dust accumulation in the last 130,000 yr for the Chinese Loess Plateau. Quaternary Research 67(1): 152-160, DOI 10.1016/j.yqres.2006.08.003.

Madsen AT and Murray AS, 2009. Optically stimulated luminescence dating of young sediments: A review. Geomorphology 109(1-2): 316, DOI 10.1016/j.geomorph.2008.08.020.

Murray AS and Wintle AG, 2000. Luminescence dating of quartz using an improved single-aliquot regenerative-dose protocol. Radiation Measurements 32(1): 57-73, DOI 10.1016/S1350-4487(99)00253$\mathrm{X}$.

Murray AS and Olley JM, 2002. Precision and accuracy in the optically stimulated luminescence dating of sedimentary quartz: a status review. Geochronometria 21: 1-16.

Musson FM, Clarke ML and Wintle AG, 1994. Luminescence dating of loess from the Liujiapo section, central China. Quaternary Science Reviews 13(5-7): 407-410, DOI 10.1016/0277-3791(94)90050-7.

Olley JM, Caitcheon GC and Murray AS, 1998. The distribution of apparent dose as determined by optically stimulated luminescence in small aliquots of fluvial quartz: implications for dating young sediments. Quaternary Science Reviews 17(11): 1033-1040, DOI 10.1016/S0277-3791(97)00090-5.

Prescott J, 1983. Thermoluminescence dating of sand dunes at Roonka, Australia. Council of Europe Journal PACT 9: 505-512.

Rees-Jones J, 1995. Optical dating of young sediments using fine-grain quartz. Ancient TL 13: 9-14.

Rees-Jones J and Tite MS, 1994. Recuperation of IRSL after bleaching and consequences for dating young sediment. Radiation Measurements 23(2-3): 569-574, DOI 10.1016/1350-4487(94)90101-5.

Roberts HM, 2008. The development and application of luminescence dating to loess deposits: a perspective on the past, present and future. Boreas 37(4): 483-507, DOI 10.1111/j.15023885.2008.00057.x.

Roberts HM and Wintle AG, 2001. Equivalent dose determinations for polymineralic fine-grains using the SAR protocol: application to a Holocene sequence of the Chinese Loess Plateau. Quaternary Science Reviews 20(5-9): 859-863, DOI 10.1016/S02773791(00)00051-2.

Roberts HM and Wintle AG, 2003. Luminescence sensitivity changes of polymineral fine grains during IRSL and [post-IR] OSL measurements. Radiation Measurements 37(6): 661-671, DOI 10.1016/S1350-4487(03)00245-2.

Stevens T, Armitage SJ, Lu H and Thomas DSG, 2006. Sedimentation and diagenesis of Chinese loess: implications for the preservation of continuous high-resolution climate records. Geology 34: 849852, DOI 10.1130/G22472.1.

Thiel C, Buylaert J-P, Murray A, Terhorst B, Hofer I, Tsukamoto S and Frechen M, 2011a. Luminescence dating of the Stratzing loess profile (Austria) - Testing the potential of an elevated temperature
post-IR IRSL protocol. Quaternary International 234(1-2): 23-31, DOI 10.1016/j.quaint.2010.05.018.

Thiel C, Buylaert JP, Murray AS, Terhorst B, Tsukamoto S, Frechen M and Sprafke T, 2011b. Investigating the chronostratigraphy of prominent palaeosols in Lower Austria using post-IR IRSL dating. Quaternary Science Journal (E\&G) 60(1): 137-152, DOI 10.3285/eg.60.1.10.

Thiel C, Buylaert JP, Murray AS and Tsukamoto S, 2011c. On the applicability of post-IR IRSL dating to Japanese loess. Geochronometria 38(4): 369-378, DOI 10.2478/s13386-011-0043-4.

Thomsen KJ, Murray AS, Jain M and Bøtter-Jensen L, 2008. Laboratory fading rates of various luminescence signals from feldspar-rich sediment extracts. Radiation Measurements 43(9-10): 1474-1486, DOI 10.1016/j.radmeas.2008.06.002.

Thomsen KJ, Murray AS and Jain M, 2011. Stability of IRSL signals from sedimentary K-feldspar samples. Geochronometria 38(1): 113, DOI 10.2478/s13386-011-0003-z.

Tsukamoto S, Fukusawa H, Ono Y and Fang X-M, 2001. Infrared stimulated luminescence and thermoluminescence dating of loess from Lanzhou, China. The Quaternary Research 40(5): 385-392.

Vandenberghe D, Derese C, Houbrechts G, 2007. Residual doses in recent alluvial sediments from the Ardenne (S Belgium). Geochronometria 28: 1-8, DOI 10.2478/v10003-007-0024-z.

Wallinga J, 2002. Optically stimulated luminescence dating of fluvial deposits: a review. Boreas 31(4): 303-322, DOI 10.1111/j.15023885.2002.tb01076.x.

Wallinga J, Murray A and Duller G, 2000. Underestimation of equivalent dose in single- aliquot optical dating of feldspars caused by preheating. Radiation Measurements 32(5-6): 691-695, DOI 10.1016/S1350-4487(00)00127-X.

Wang X, Lu Y and Zhao H, 2006. On the performances of the singlealiquot regenerative-dose (SAR) protocol for Chinese loess: fine quartz and polymineral grains. Radiation Measurements 41(1): 18, DOI 10.1016/j.radmeas.2005.02.010.

Watanuki T, Murray AS and Tsukamoto S, 2003. A comparison of OSL ages derived from silt-sized quartz and polymineral grains from Chinese loess. Quaternary Science Reviews 22(10-13): 991-997, DOI 10.1016/S0277-3791(03)00053-2.

Wintle AG and Murray AS, 2006. A review of quartz optically stimulated luminescence characteristics and their relevance in singlealiquot regeneration dating protocols. Radiation Measurements 41(4): 369-391, DOI 10.1016/j.radmeas.2005.11.001.

Zhang JF and Zhou LP, 2007. Optimization of the 'double SAR' procedure for polymineral fine grains. Radiation Measurements 42(9): 1475-1482, DOI 10.1016/j.radmeas.2007.06.007.

Zhou LP, Fu DP and Zhang JF, 2010. An analysis of the components of the luminescence signals of selected polymineral and quartz samples from loess in western China and southern Tajikistan, and their suitability for optical dating. Quaternary Geochronology 5(2-3): 149-153, DOI 10.1016/j.quageo.2009.05.008. 